Kristian Z. Kovač, Ph.D. Student

University of Novi Sad

Faculty of Law Novi Sad

kristian.kovac@yahoo.com

\title{
INTERNATIONAL LEGAL ASPECTS OF THE CHAGOS ARCHIPELAGO CASE
}

\begin{abstract}
Chagos Archipelago is a territory that was detached from Mauritius in 1965 on the basis of the Lancaster House Agreement concluded between the governments of the United Kingdom and Mauritius, a colony of the United Kingdom in that period. That same year, the United Kingdom founded the British Indian Ocean Territory, which includes, inter alia, the territory of this archipelago. Mauritius gained its independence on 12th March 1968, while the Chagos Archipelago remained under the colonial rule of the United Kingdom. Mauritius continues to regard the Chagos Archipelago as its own territory, and is continually trying to use available international legal mechanisms to challenge the 1965 detachment of the Chagos Archipelago. The author investigates the international legal aspects of the longstanding dispute between Mauritius and the United Kingdom, such as the issue of the depopulation of the Chagos Archipelago, the unilateral proclamation of a Marine Protected Area by the United Kingdom in 2010, regarding which Mauritius initiated an arbitration award under the 1982 United Nations Convention on the Law of the Sea (UNCLOS), as well as the issues of decolonization and the right of the people to self-determination, regarding which the United Nations General Assembly requested by Resolution 71 / 292 of 22 June 2017 an Advisory Opinion of the International Court of Justice on the subject matter. The Advisory Opinion of the International Court of Justice was made on 25th February 2019.
\end{abstract}

Keywords: decolonisation, right to self-determination, human rights, marine protected area, International Court of Justice.

\section{INTRODUCTION}

On $25^{\text {th }}$ February 2019, the International Court of Justice (hereinafter - ICJ) adopted the Advisory Opinion on the Legal consequences of the separation of the 
Chagos Archipelago from Mauritius in $1965 .{ }^{1}$ In this Advisory Opinion, the ICJ expressed the view that the United Kingdom of Great Britain and Northern Ireland (hereinafter - the UK) is under an obligation to bring to an end its administration of the Chagos Archipelago as rapidly as possible. ${ }^{2}$ The proceedings before the ICJ were initiated on the basis of United Nations (hereinafter - UN) General Assembly Resolution 71/292. ${ }^{3}$ This ICJ procedure was preceded by a long-standing dispute between Mauritius and the UK, which has more international legal aspects, such as the issue of the depopulation of the Chagos Archipelago, the issue of the unilateral proclamation of a Marine Protected Area (hereinafter - MPA) by the UK 2010, regarding which Mauritius initiated an arbitration award under the 1982 United Nations Convention on the Law of the Sea (UNCLOS), ${ }^{4}$ as well as the issues of decolonization and the right of the people to self-determination, regarding which the UN General Assembly requested by Resolution 71 / 292 of 22 June 2017 an Advisory Opinion of the International Court of Justice on the subject matter. In order to research the mentioned international legal aspects of the Chagos Archipelago case, it is firstly necessary to explain the historical background and the factual circumstances of this case.

\section{HISTORICAL BACKGROUND AND THE FACTUAL CIRCUMSTANCES OF THE CHAGOS ARCHIPELAGO CASE}

The Chagos Archipelago is located in the Indian Ocean, south of India, about halfway between Africa and Indonesia, and it consist of numerous islands and atolls, the biggest of which is the island of Diego Garcia. ${ }^{5}$ Between 1814 and 1965, the Chagos Archipelago was administered by the UK, as the territory of Mauritius, which was under UK colonial rule. The first colonial administration of Mauritius was established in 1715 by France which named it Ile de France. ${ }^{6}$ In 1810, the British captured Ile de France and renamed it Mauritius. ${ }^{7}$ By the Treaty of Paris of 1814, France ceded Mauritius and all its dependencies to the United Kingdom. ${ }^{8}$

${ }^{1}$ ICJ, Legal Consequences of the Separation of the Chagos Archipelago From Mauritius In 1965 (Advisory Opinion), 2019, https://www.icj-cij.org/files/case-related/169/169-20190225-01-00-EN. pdf, 1st. April 2019.

${ }^{2}$ Ibid. para. 183.

${ }^{3}$ UN General Assembly Resolution A/RES/71/292 2017 (Resolution 71/292), https://www. un.org/en/ga/search/view_doc.asp?symbol=A/RES/71/292, 1st April 2019.

${ }^{4}$ United Nations Convention on the Law of the Sea (UNCLOS), http://www.un.org/depts/ los/convention_agreements/texts/unclos/unclos_e.pdf, 1st April 2019.

${ }^{5}$ See. British Indian Ocean Territory, https://www.cia.gov/library/publications/the-worldfactbook/geos/print_io.html, 1th April 2019.

${ }^{6}$ Advisory Opinion, para. 27.

${ }^{7}$ Ibid.

${ }^{8}$ Ibid. 
After World War II, the issue of decolonization was opened, and on 14th December 1960, the UN General Assembly adopted the Resolution 1514 (XV),, Declaration on the granting of independence to colonial countries and peoples", 9 which accelerated the process of decolonization. During 1964., the United States of America (hereinafter - USA) expressed an interest in establishing military facilities on the island of Diego Garcia., and discussions commenced between the USA and the UK regarding this subject..$^{10}$ On 23th September 1965, the representatives of the Mauritius colony concluded the Lancaster House Agreement with the UK Government, which defined the detachment of the Chagos Archipelago from Mauritius, and in December that year, the UK founded the British Indian Ocean Territory (hereinafter - BIOT) which consists from the Chagos Archipelago and three island's detached from Seychelles ${ }^{11}{ }^{12}$ In 1966, the UK and the USA concluded an agreement by which the island of Diego Garcia was leased to the United States for 50 years for defense purposes (establishment of a military base), with the possibility of extending it to an additional 20 years. ${ }^{13}$ From 1967 to 1973, all the local population of the Chagos Archipelago ${ }^{14}$ were either prevented from returning to the territory of the archipelago or forcibly removed and prevented from returning by the UK, while the main forcible removal of Diego Garcia's population took place in July and September 1971, on the basis of administrative decision of the UK to satisfy USA defense needs. ${ }^{15}$ Mauritius gained independence on 12th March 1968, while the Chagos Archipelago remained under the colonial administration of the UK. Mauritius still considers the Chagos Archipelago as its own territory, and is continuously trying to use the available legal mechanisms to challenge the detachment of the Chagos Archipelago in 1965. On the territory of the Chagos Archipelago, the UK unilaterally proclaimed a MPA, regarding which Mauritius initiated an arbitration award under the UNCLOS. With the adoption of the Resolution 71/292 on 22 ${ }^{\text {nd }}$ June 2017, the UN General Assembly initiated proceedings before the ICJ for the adoption of an Advisory Opinion, about the question of compliance of the process of decolonization of Mauritius completed

${ }^{9}$ UN General Assembly Resolution A/RES/15/1514 (XV) 1960 „Declaration on the granting of independence to colonial countries and peoples“ (Resolution 1514), https://undocs.org/A/Res/ 1514(XV), $2^{\text {nd }}$ April 2019.

${ }^{10}$ See. Advisory Opinion, para. 31.

${ }^{11}$ Aldabra, Farquhar and Desroches islands.

${ }^{12}$ See. Advisory Opinion, para. 32,33.

${ }^{13}$ See. Agreement concerning the availability for defense purposes of the British Indian Ocean Territory, https://treaties.un.org/doc/Publication/UNTS/Volume\%20603/volume-603-I8737-English.pdf, 2nd April 2019.

14 The population of the Chagos Archipelago are also known as Chagossians or Ilois (the Islanders). They have African, Malayan and Indian origin.

${ }^{15}$ See. Advisory Opinion, para. 37,43. 
with the international law, as well as about the consequences under international law arising from the continued administration by the UK of the Chagos Archipelago. ${ }^{16}$

\section{DEPOPULATION OF THE CHAGOS ARCHIPELAGO}

The depopulation of the Chagos Archipelago was carried out between 1967 and 1973, in which period the entire population of the Chagos Archipelago, was either prevented from returning or forcibly removed and prevented from returning by the UK. ${ }^{17}$ According to the UK regulations, since 1971, the arrival or stay of any person in the territory of the Chagos Archipelago without a permit, has been declared illegal. Between 1971 and 1982, negotiations were conducted between the UK and Mauritius, as well as Seychelles, which resulted in the establishment of a trust fund by the UK Government as compensation for the displaced population of the Archipelago.$^{18}$ In the period between 1983 and 1984, the sum of approximately 4 million British Pounds paid by the UK was disbursed to 1,344 Chagossians with a condition for collecting the funds, that the islanders sign or to place a thumbprint on a form renouncing their right to return to the Chagos Archipelago. ${ }^{19}$ The form was a one-page legal document, written in English, without a Creole translation, and only 12 persons refused to sign this document. ${ }^{20}$

Among the important international institutions, the issue of violation of human rights of the inhabitants of the Chagos Archipelago was a subject of activity of the Committee on the Elimination of Racial Discrimination established by Article 8 of the International Convention on the Elimination of All Forms of Racial Discrimination $^{21}$, the Human Rights Committee established by Article 28 of the International Covenant on Civil and Political Rights ${ }^{22}$, and also, the natives of, or descendants of natives of the Chagos Archipelago submitted an application

${ }^{16}$ See. Resolution $71 / 292$.

${ }^{17}$ Advisory Opinion, para. 43.

${ }^{18}$ See. British Indian Ocean Territory, https://www.cia.gov/library/publications/the-worldfactbook/geos/print_io.html, 1st April 2019.

${ }^{19}$ See. Advisory Opinion, para. 120.

${ }^{20}$ See. Ibid.,

${ }^{21}$ International Convention on the Elimination of All Forms of Racial Discrimination Adopted and opened for signature and ratification by General Assembly resolution 2106 (XX) of 21 December 1965, https://www.ohchr.org/Documents/ProfessionalInterest/cerd.pdf, 4th April 2019.

${ }^{22}$ International Covenant on Civil and Political Rights 1960 - ICCPR, https://treaties.un. org/doc/publication/unts/volume\%20999/volume-999-i-14668-english.pdf, 4th April 2019. 
to the European Court of Human Rights (hereinafter - ECHR) on 20th September 2004, citing violations of Article 3 (Prohibition of torture), Article 6 (Right to a fair trial), Article 8 (Right to respect for private and family life) and Article 13 (The right to an effective remedy) of the Convention for the Protection of Human Rights and Fundamental Freedoms ${ }^{23}$ and Article 1 (Protection of property) of Protocol no. 1 of this Convention. ${ }^{24}$

The Committee on the Elimination of Racial Discrimination considers the situation of the Chagos Archipelago in its Concluding observations on the UK. ${ }^{25}$ In 2003, this Committee expressed regret that the UK had not provided any information on the implementation of the Convention in the BIOT in its report, while in 2006, the UK replied to the Committee that the Convention does not apply to the BIOT bearing in mind that BIOT has no permanent inhabitants.. ${ }^{26}$ In 2011, the Committee expressed concern about the UK position regarding the application of the Convention in the BIOT, and it reminded the UK that the Convention is applicable to all territories under its control. ${ }^{27}$ In the Concluding observations on the twenty-first to twenty-third periodic reports of UK, the Committee expressed its regrets that no progress has been made to implement the Committee's previous recommendation to withdraw all discriminatory restrictions on Chagossians (Ilois) from entering Diego Garcia or other islands in the Chagos Archipelago. ${ }^{28}$ Also, the Committee expressed its regrets, due to the fact that the UK continues to maintain its position that the Convention does not apply to the BIOT on the grounds that it has no permanent population and that it has not yet extended the application of the Convention to the BIOT. ${ }^{29}$

${ }^{23}$ Convention for the Protection of Human Rights and Fundamental Freedoms (CETS No.005), 04.11.1950, https://rm.coe.int/1680063765, 4th April 2019.

${ }^{24}$ See. Chagos Islanders v. The United Kingdom, No. 35622/04, para. 32-36, ECHR 20/12/ 2012.

${ }^{25}$ See. Amy Schwebel, „International Law and Indigenous People's Rights: What Next for the Chagossians", Fifty Years of the British Indian Ocean Territory: Legal Perspectives, Stephen Allen, Chris Monaghan (eds.), Springer International Publishing AG, part of Springer Nature, Cham, Switzerland, 2018, 329.

${ }^{26}$ See. Submission to the Committee on the Elimination of Racial Discrimination By Minority Rights Group International, International Non-Governmental Organisation with ECOSOC Consultative Status, United Kingdom of Great Britain and Northern Ireland 90th Session, 2-26 August 2016., 3,4, https://tbinternet.ohchr.org/Treaties/CERD/Shared\%20Documents/GBR/INT_ CERD_IFN_GBR_24489_E.pdf, 4th April 2019.

${ }^{27} \mathrm{Ibi} \bar{d}$.

${ }^{28}$ Concluding observations on the twenty-first to twenty-third periodic reports of United Kingdom of Great Britain and Northern Ireland, Committee on the Elimination of Racial Discrimination, CERD/C/GBR/CO/21-23, 26 August 2016, 9, https://tbinternet.ohchr.org/Treaties/ CERD/Shared\%20Documents/GBR/CERD_C_GBR_CO_21-23_24985_E.pdf, 3th April 2019.

${ }^{29}$ Ibid. 
The Human Rights Committee, considering the periodic reports submitted by the United Kingdom in 2001, noted that the UK's acceptance that its prohibition of the return of Chagossians who had left or been removed from the territory was unlawful, and it recommended that the UK should, to the extent still possible, seek to make exercise of the Chagossians' right to return to their territory practicable. ${ }^{30}$ The UK didn't submitted reports to the Human Rights Committee about the territory of BIOT, stating that BIOT has no permanent population, which represents the same argument which the UK expressed when excluded the BIOT territory from the periodic reports submitted to the Committee on the Elimination of Racial Discrimination. In the Concluding observations of the Human Rights Committee on the subject of the Consideration of Reports Submitted by States Parties Under Article 40 of the ICCPR, the Committee regrets that, despite its previous recommendation, the UK has not included the BIOT in its periodic report because it claims that, owing to an absence of population, the ICCPR does not apply to this territory. ${ }^{31}$ The Committee recommended, that the UK should ensure that the Chagossians can exercise their right to return to their territory, and that it should include the BIOT in its next periodic report. ${ }^{32}$ In the following, seventh periodic report which the UK submitted in April 2013, the BIOT territory was included in the report. In this report, it is emphasized, that in 2008, the Law Lords (the Supreme Court of the UK) confirmed that no person has the right of abode in BIOT or the right to enter the BIOT unless authorized. In addition, it is mentioned that a case has been brought against the UK at the ECHR around these issues. ${ }^{33}$

A group of 1786 natives of, or descendants of natives of the Chagos Archipelago, on 20th September 2004, submitted an application to the ECHR citing violations of Articles 3, 6, 8, 13 of the European Convention on Human Rights and Article 1 of Protocol no. 1 of this Convention by the UK. The ECHR declared this application inadmissible for formal reasons, without entering into a merit-based resolution of the allegations contained in the application. Namely, having accepted and received compensation and thus having effectively renounced on bringing any further local remedies, the applicants could therefore no longer claim

${ }^{30}$ Advisory Opinion, para. 123.

${ }^{31}$ See. Concluding observations of the Human Rights Committee - Consideration of Reports Submitted by States Parties Under Article 40 of the Covenant, Human Rights Committee, CCPR/C/ GBR/CO/6 30 July 2008, para. 22., https://tbinternet.ohchr.org/layouts/treatybodyexternal/Download.aspx?symbolno $=C C P R / C / G B R / C O / 6 \& L a n g=F r$, 5th April 2019.

${ }^{32}$ Ibid.

${ }^{33}$ See. Seventh periodic reports of States parties due in July 2012 United Kingdom, the British Overseas Territories, the Crown Dependencies - Consideration of Reports Submitted by States Parties Under Article 40 of the Covenant, Human Rights Committee, CCPR/C/GBR/7, 29 April 2013, para. 206., https://assets.publishing.service.gov.uk/government/uploads/system/uploads/attachment_data/file/398147/ccpr-c-gbr-7.pdf, $5^{\text {th }}$ April 2019. 
to be victims of a violation of the Convention. ${ }^{34}{ }^{35}$ Also, the argument that not all the applicants had signed the waiver forms in the settlement or had not realised that the settlement was final was rejected by the ECHR. ${ }^{36}$ As concerned the applicants who were not born at the time of the settlement, the ECHR noted that they had never had a home on the islands and could therefore have no claim to victim status arising out of the expulsions and their immediate aftermath. ${ }^{37}$ Finally, the ECHR didn't found any indication of arbitrariness or unfairness in the proceedings before the national courts of the UK, which the applicants had previously initiated, and which could be construed as a denial of access to court. ${ }^{38}$

\section{PROCLAMATION OF A MARINE PROTECTED AREA}

On 10th April 2010, the UK unilaterally proclaimed a MPA on the territory of the Chagos Archipelago, which is one of the largest marine protected areas on the world. This area spreads on the territory of $640.000 \mathrm{~km} 2$. The creation of this MPA included, among other provisions, the prohibition of anything but recreational fishing. ${ }^{39}{ }^{40}$ On 20th December 2010, Mauritius initiated proceedings against

${ }^{34}$ Article 34 of the European Convention on Human Rights prescribes that the „, The Court may receive applications from any person, non-governmental organisation or group of individuals claiming to be the victim of a violation by one of the High Contracting Parties of the rights set forth in the Convention or the Protocols thereto. The High Contracting Parties undertake not to hinder in any way the effective exercise of this right". Status of a potential victim presupposes the existence of a high probability that an individual has been affected or could be affected by violation of human right. In spite of broad and flexible interpretation of the status of victim, certain personal detrimental impact of violation of human right is necessary as a criterion for the admissibility of an individual application before the ECHR; Rodoljub Etinski, ,Specific Features of Human Rights Guaranteed by the Aarhus Convention“, Zbornik radova Pravnog fakulteta u Novom Sadu (Zbornik radova PFNS), 2/2013, 86,87.

${ }^{35}$ Chagos islanders' case inadmissible because they accepted compensation and waived the right to bring any further claims before the UK national courts, Press Release issued by the Registrar of the Court, ECHR 460 (2012)

20.12.2012, 3,https://www.google.com/url? $s a=t \& r c t=j \& q=\&$ esrc $=s \&$ source $=w e b \& c d=1 \&$ ved $=2$ ahUKEwiinKS_qMbhAhUPcZoKHSYUBXQQFjAAegQIABAC\&url=https $\% 3 \mathrm{~A} \% 2 \mathrm{~F} \% 2 \mathrm{Fhu}$ doc.echr.coe.int $\% 2$ Fapp $\% 2$ Fconversion $\% 2$ Fpdf\% 2 F\%3Flibrary\%3DECHR\%26id\%3D0034207010-4992253\%26filename\%3D003-4207010-4992253.pdf\&usg=AOvVaw3dVUujf72zoeWnkv CnYWhw, 5th April 2019.

${ }^{36}$ Ibid.

${ }^{37}$ Ibid.

${ }^{38}$ Ibid.

${ }^{39}$ Awaz Raoof, ,Still dispossessed - the battle of the Chagos Islanders to return to their homeland",Minority Rights Group International, 4, https://minorityrights.org/wp-content/uploads/2015/07/MRG_Brief_Chagosv2.pdf, 11th April 2019.

${ }^{40}$ It is interesting to note that Mauritius, in the proceedings before the Arbitral Tribunal, based one of its arguments on a dispatch of the USA Embassy in London from 15th May 2009, 
the UK under Article 287 of the UNCLOS, challenging the unilateral establishment of the MPA by the UK, which proceeded before an Arbitral Tribunal constituted under Annex VII of the UNCLOS. In this proceedings, Mauritius claimed that: 1) the UK was not entitled to declare a MPA or other maritime zones in and around the Chagos Archipelago as it was not a coastal State within the meaning of UNCLOS; 2) the UK was not entitled to declare unilaterally a MPA or other maritime zones because Mauritius had rights as a coastal State within the meaning UNCLOS; 3) the UK should not take any steps to prevent the Commission on the Limits of the Continental Shelf from making recommendations to Mauritius in respect of any submission that Mauritius may make to that Commission regarding the Chagos Archipelago; and (4) the MPA was incompatible with the UK's obligations under UNCLOS. ${ }^{41}$ On 18 March 2015, the Arbitral Tribunal rendered an Award, in which it found, that it lacked jurisdiction on Mauritius' first, second and third submissions. On the merits, the Arbitral Tribunal found, inter alia, that, in establishing the MPA surrounding the Chagos Archipelago, the UK had breached its obligations under Article 2, paragraph 3 (sovereignty over the territorial sea), Article 56, paragraph 2 (exercising rights and performing duties in the exclusive economic zone), and Article 194, paragraph 4 (measures for prevention, reduction or control pollution of the marine environment), of the UNCLOS, and that the UK's undertaking to return the Chagos Archipelago to Mauritius, when no longer needed for defence purposes, was legally binding. ${ }^{42}$ The Arbitral Tribunal found that it was undisputed that Mauritius was affected by the proclamation of the MPA, primarily regarding the prohibition of fishing. ${ }^{43}$

published by WikiLeaks in 2010, declaring that the UK's intentions for the establishment of the MPA was not environmental protection, but the prevention of the return of the evicted population of the Chagos Archipelago. This could also be indicated by the fact, that the proclamation of the MPA happened in the same time when the proceedings before the ECHR were ongoing, on the basis of the application of natives of, or descendants of natives of the Chagos Archipelago; See. Marina Aksenova, Ciarán Burke, „The Chagos Islands Award: Exploring the Renewed Role of the Law of the Sea in the Post-Colonial Context", Wisconsin International Law Journal, Vol. 35, No. 1, 2017, 15.; Hmg Floats Proposal for Marine Reserve Covering the Chagos Archipelago (British Indian Ocean Territory), https://wikileaks.org/plusd/cables/09LONDON1156_a.html, 15th April 2019.

${ }^{41}$ Advisory Opinion, para. 48.

${ }^{42} \mathrm{Ibid}$. para. 50

${ }^{43}$ The Arbitral Tribunal Award in the Matter of the Chagos Marine Protected Area Arbitration before an Arbitral Tribunal Constituted under Annex VII of the United Nations Convention on the Law of the Sea betweent the Republic of Mauritius and the United Kingdom of Great Britain and Northern Ireland, Permanent Court of Arbitration, 18 March 2015, para. 521. http://www. pcacases.com/pcadocs/MU-UK\%2020150318\%20Award.pdf, $12^{\text {th }}$ April 2019. 


\section{DECOLONISATION AND THE RIGHT TO SELF-DETERMINATION}

On $22^{\text {nd }}$ June 2017, the UN General Assembly adopted the Resolution 71/29244, in which it requests an advisory opinion of the ICJ on the following questions: 1) Was the process of decolonization of Mauritius completed in compliance with the international law, when Mauritius was granted independence in 1968, following the separation of the Chagos Archipelago from Mauritius; 2) What are the consequences under international law arising from the continued administration by the UK of the Chagos Archipelago, including with respect to the inability of Mauritius to implement a program for the resettlement on the Chagos Archipelago of its nationals, in particular those of Chagossian origin. ${ }^{45}$

On 25th February 2019, the ICJ adopted the Advisory Opinion on the legal consequences of the separation of the Chagos Archipelago from Mauritius in 1965. The main subject of the consideration of the ICJ was the issue of the decolonization of Mauritius and the right of the people of Mauritius to self-determination. This issue also tangles the principle of uti possideti juris. All post-independence Mauritian governments reclaimed sovereignty over the Chagos Archipelago, pointing to the 1965 "excision" as a violation of the UN General Assembly's Decolonization Resolutions 1514 (XV) and 2066 (XX),23 and of the uti possideti rule. ${ }^{46}$ Firstly, it is necessary to summarize what is the principle of uti possideti. The principle of uti possidetis is the principle of international law that „freezes" the territorial title and converts the administrative boundary into an interstate border. ${ }^{47}$ This principle was used to define postcolonial borders in Latin America, Asia, and Africa, as a doctrine according to which new independent states inherited administrative boundaries from the pre-decolonization period, determined by the metropole countries. ${ }^{48}$ The doctrine is based on the fact that the legal basis for acquiring a certain territory, a former colony, prevails over other opposing requests

${ }^{44}$ The Resolution 71/292 was adopted by 89 votes with 9 abstentions. According to the opinion of Gifkins, Jarvis and Ralph, the lack of support to the UK by EU member states during the mentioned UN General Assembly vote (only four EU member states supported the UK position) is the result of Brexit; See. Jess Gifkins, Samuel Jarvis, Jason Ralph, „Global Britain in the United Nations“, 12, https://www.una.org.uk/sites/default/files/UNA-UK_GlobalBritain_20190207d. $p d f, 14^{\text {th }}$ Apirl 2019.

45 See. Resolution 71/292.

${ }^{46}$ Peter Sand, ,The Chagos Archipelago Cases: Nature Conservation Between Human Rights and Power Politics", Giuliana Ziccardi Capaldo (ed.), The Global Community Yearbook of International Law \& Jurisprudence, 2013 (I), 128.

${ }^{47}$ Rodoljub Etinski, ,Primena načela uti possidetis u sporu o granici između Burkina Faso i Malija“, Zbornik radova PFNS, , 3/2013, 48.

${ }^{48}$ Bojan Tubić, ,Rešavanje teritorijalnih sporova u međunarodnom pravu “, Zbornik radova PFNS, 4/2015, 1868. 
based on occupation. ${ }^{49}$ Decolonization took place along the colonial boundaries, bearing in mind that this was the simplest and fastest way for it. ${ }^{50}$ The uti possidetis principle assumes that internal, administrative boundaries are functionally equivalent to international borders..$^{51}$ It prevented unrests and major conflicts in the post-colonial era in Asia, Africa and Latin America. The uti possidetis juris principle is connected with the principle of self-determination defined in the UN Charter. ${ }^{52}$

In the Advisory Opinion of the ICJ in the case of Chagos Archipelago, the ICJ does not explicitly refer to the principle of uti possidetis juris. However, the ICJ invokes the rule on the inviolability of the territorial integrity of the colonized state in declaring independence, defined by paragraph 6 of the Resolution 1514 of the UN General Assembly. ${ }^{53}$ Namely, this paragraph prescribes, that any attempt aimed at the partial or total disruption of the national unity and the territorial integrity of a country is incompatible with the purposes and principles of the Charter of the UN. ${ }^{54}$ Bearing in mind that the principle of uti possidetis juris implies taking into account administrative boundaries that are equated with international borders when considering the independence of colonized states, the wording of paragraph 6 of UN General Assembly Resolution 1514 can be considered, in the context of decolonization as the subject of regulation this Resolution, as some sort of derivate of the uti possidetis juris principle.

The principle of uti possidetis juris, as well as the Resolution 1514, are connected with the right to self-determination. This is confirmed also by the ICJ in the mentioned Advisory Opinion. First of all, it is interesting to notice that the ICJ in it's Advisory Opinion limited its analysis of the right to self-determination only to decolonization cases. ${ }^{55}$ In this way, the Court avoided the possibility of invoke the conclusions of the Court from this Advisory Opinion in other (numerous) disputable cases which exist in practice, and which are concerning the existence of the right to self-determination, and in which there is a "conflict" between the right to self-determination (pure fact approach) and sovereignty (legal approach). ${ }^{56}$

49 Ibid.

${ }^{50}$ Bojan Tubić, „Primena načela uti possidetis juris pri određivanju međudržavnih granica“, Zbornik radova PFNS , 3/2011, 655

${ }^{51}$ B. Tubić (2015), 1868.

52 B. Tubić (2011), 654; See. i ICJ, Case Concerning the Frontier Dispute (Burkina Faso/ Republic of Mali), Judgment of 22 December 1986, https://www.icj-cij.org/files/case-related/69/06919861222-JUD-01-00-EN.pdf, 26th May 2019.

${ }^{53}$ See. Advisory Opinion, para. 153.

${ }^{54}$ Resolution 1514, para. 6.

55 See. Advisory Opinion, para. 144.

${ }^{56}$ For more about the pure fact approach and legal approach, See. Martti Koskenniemi, From Apology to Utopia - The Structure of International Legal Argument, Helsinki 1989, pp. 236-261. 
In the Advisory Opinion, the ICJ considered whether the right of self-determination was, in the context of decolonization, the rule of international customary law in the period from 1965 to $1968 .{ }^{57}$ Firstly, the ICJ points out that, according to Article 38 of the ICJ Statute, a custom is constituted through "general practice accepted as law", more precisely, that for the existence of international customary rule, there must be a settled practice (objective element), as well as opinio juris sive necessitatis - the States concerned must feel that they are conforming to what amounts to a legal obligation (subjective element). ${ }^{58}$ In the opinion of the ICJ, the adoption of Resolution 1514 represents a defining moment in the consolidation of State practice on decolonization..$^{59}$ Namely, in the Court's view, there is a clear relationship between Resolution 1514 and the process of decolonization following its adoption. ${ }^{60}$ During the 1960s, the peoples of an additional 28 non-self-governing-territories exercised their right to self-determination and achieved independence. ${ }^{61}$ Also, the Court considered that, although Resolution 1514 is formally a recommendation, it has a declaratory character with regard to the right to self-determination as a customary norm, in view of its content and the conditions of its adoption. ${ }^{62}$ The Resolution was adopted by 89 votes with 9 abstentions, and none of the States participating in the vote contested the existence of the right of peoples to self-determination. ${ }^{63} \mathrm{On}$ the other hand, the wording used in this Resolution has a normative character, in so far as it affirms that all peoples have the right to self-determination. ${ }^{64}$

By the opinion of the Court, both State practice and opinio juris at the relevant time confirm the customary law character of the right to territorial integrity of a non-self-governing territory as a corollary of the right to self-determination. ${ }^{65}$ The Court pointed out, that no example has been brought to the attention of the Court in which, following the adoption of Resolution 1514, the General Assembly or any other organ of the UN has considered as lawful the detachment by the administering Power of part of a non-self-governing territory, for the purpose of maintaining it under its colonial rule. ${ }^{66}$ Also, ICJ stated that States have consistently emphasized that respect for the territorial integrity of a non-self-governing

\footnotetext{
${ }^{57}$ See. Ibid. para. 148.

58 Ibid. para. 149.

${ }^{59}$ See. Ibid., para. 150.

${ }^{60}$ Ibid.

${ }^{61}$ Ibid.

${ }^{62}$ Ibid. para. 152.

${ }^{63}$ Ibid.

${ }^{64}$ Ibid. para. 153.

${ }^{65} \mathrm{Ibid}$. para. 160.

${ }^{66}$ Ibid.
} 
territory is a key element of the exercise of the right to self-determination under international law. ${ }^{67}$ The ICJ emphasized, that the peoples of non-self-governing territories are entitled to exercise their right to self-determination in relation to their territory as a whole, the integrity of which must be respected by the administering Power. ${ }^{68}$ It follows that any detachment by the administering Power of part of a non-self-governing territory, unless based on the freely expressed and genuine will of the people of the territory concerned, is contrary to the right to self-determination. ${ }^{69}$

Regarding the question of whether there was a freely expressed and genuine will of the people of Mauritius for the detachment of the Chagos Archipelago, the ICJ found, that due to the fact that at the time when the Lancaster House Agreement was concluded, Mauritius was under colonial rule of the UK, it is not possible to talk of an international agreement, when one of the parties to it, Mauritius, which is said to have ceded the territory to the United Kingdom, was under the authority of the latter. ${ }^{70}$ On this issue, the Court also mentions the report of the Committee of Twenty-Four (Decolonization Committee) of 1964, in which this Committee pointed out that the Constitution of Mauritius didn't allow to the representatives of the people of Mauritius to exercise real powers, and that authority was virtually all concentrated in the hands of the UK Government. ${ }^{71}$ Bearing in mind all the mentioned, the detachment of the Chagos Archipelago was not based on the free and genuine expression of the will of the people concerned. ${ }^{72}$

Regarding the UN General Assembly question, what are the consequences under international law arising from the continued administration by the UK of the Chagos Archipelago, the ICJ concluded that since the decolonization of Mauritius was not conducted in a manner consistent with the right of peoples to self-determination, it follows that the UK's continued administration of the Chagos Archipelago constitutes a wrongful act entailing the international responsibility of that State. ${ }^{73}$ Because of this, the UK is under an obligation to bring to an end its administration of the Chagos Archipelago as rapidly as possible. ${ }^{74}$ Also, the Court concluded that all UN Member States are under an obligation to co-operate with the UN in order to complete the decolonization of Mauritius. ${ }^{75}$

\footnotetext{
${ }^{67}$ Ibid.

68 Ibid.

${ }^{69}$ Ibid.

${ }^{70}$ See. Ibid., para. 171, 172.

${ }^{71}$ Ibid., para. 99, 172

${ }^{72}$ Ibid. para. 172.

${ }^{73}$ Ibid. para. 177.

${ }^{74}$ Ibid. para. 183.

${ }^{75}$ Ibid.
} 


\section{CONCLUSION}

The case of the Chagos Archipelago represents a kind of treasury of international legal rules, bearing in mind the diversity of international legal issues that affect this case. From 1965 until today, this case touched the issue of human rights, proclamation of MPA, and the question of decolonization and the right of peoples to self-determination, and these issues were the subject of consideration of a number of international institutions, such as the Committee on the Elimination of Racial Discrimination, the Human Rights Committee, the ECHR, the Arbitral Tribunal constituted on the basis of Annex VII of UNCLOS, the UN General Assembly and the ICJ.

Despite the fact that most of these institution formed an opinion contrary to the UK standpoint, the UK continues to exercise jurisdiction over the BIOT, which includes the Chagos Archipelago. After the Award of the Arbitral Tribunal on the matter of unilateral declaration of the MPA, which was not in favor of the UK, the UK extended the lease of the Diego Garcia island to the USA, and in the same year, the Foreign and Commonwealth Office of the UK retained the prohibition of the return of the displaced population of the Chagos Archipelago. After this, Mauritius initiated the adoption of the UN General Assembly Resolution on seeking the Advisory Opinion of the ICJ.

Regarding the Advisory Opinion of the ICJ, the spokesmen of the Foreign and Commonwealth Office of the UK stated, that this is an advisory opinion, not a judgment, and that the UK Government will look at the detail of this decision of the ICJ carefully. ${ }^{76}$

On the basis of Article 76, paragraph 8 of the UNCLOS, Mauritius submitted to the Commission on the Limits of the Continental Shelf, information on the limits of the continental shelf beyond 200 nautical miles from the baselines from which the depth of the territorial sea is measured concerning the Southern Chagos Archipelago region. ${ }^{77}$ The consideration of the partial submission made by Mauritius will be included in the provisional agenda of the fiftieth session of the Commission to be held in New York from 1 July to 16 August 2019. ${ }^{78}$

It remains to be seen, which activities will both UK and Mauritius undertake in the future regarding the Chagos Archipelago, and and whether there will be

\footnotetext{
${ }^{76}$ See. UN court rejects UK's claim of sovereignty over Chagos Islands, https://www.theguardian.com/world/2019/feb/25/un-court-rejects-uk-claim-to-sovereignty-over-chagos-islands, 15.th April 2019.

${ }^{77}$ Commission on the Limits of the Continental Shelf (CLCS) Outer limits of the continental shelf beyond 200 nautical miles from the baselines: Submissions to the Commission: Submission of the Republic of Mauritius, https://www.un.org/depts/los/clcs_new/submissions_files/submission_ mus1_82_2019.html, 15th April 2019.

${ }^{78} \overline{I b i d}$.
} 
actual changes in accordance with the decisions of the relevant international institutions to date.

\section{REFERENCES}

Agreement concerning the availability for defense purposes of the British Indian Ocean Territory, https://treaties.un.org/doc/Publication/UNTS/Volume\%20603/ volume-603-I-8737-English.pdf, 2th April 2019;

Aksenova M., Burke C., „The Chagos Islands Award: Exploring the Renewed Role of the Law of the Sea in the Post-Colonial Context", Wisconsin International Law Journal, Vol. 35, No. 1, 2017, 1-38;

Chagos Islanders v. The United Kingdom, No. 35622/04, ECHR 20/12/2012.

Chagos islanders' case inadmissible because they accepted compensation and waived the right to bring any further claims before the UK national courts, Press Release issued by the Registrar of the Court, ECHR 460 (2012) 20.12.2012, https://www. google.com/url? sa $=t \& r c t=j \& q=\&$ esrc $=s \&$ source $=w e b \& c d=1 \& v e d=2 a h U K E w i-$ inKS_qMbhAhUPcZoKHSYUBXQQFjAAegQIABAC\&url=https $\% 3 A \% 2 F \% 2 F$ hudoc.echr.coe.int $\% 2$ Fapp $\% 2$ Fconversion $\% 2 F$ pdf\% 2 F\%3Flibrary\%3DECHR \%26id\%3D003-4207010-4992253\%26filename\%3D003-4207010 4992253.pd$f \& u s g=A O v V a w 3 d V U u j f 72 z o e W n k v C n Y W h w, 5$ th April 2019;

Commission on the Limits of the Continental Shelf (CLCS) Outer limits of the continental shelf beyond 200 nautical miles from the baselines: Submissions to the Commission: Submission of the Republic of Mauritius, https://www.un.org/ depts/los/clcs_new/submissions_files/submission_musl_82_2019.html, $15^{\text {th }}$ April 2019;

Concluding observations of the Human Rights Committee - Consideration of Reports Submitted by States Parties Under Article 40 of the Covenant, Human Rights Committee, CCPR/C/GBR/CO/6 30 July 2008, https://tbinternet.ohchr.org/_layouts/treatybodyexternal/Download.aspx?symbolno $=C C P R / C / \bar{G} B R /$ $C O / 6 \&$ Lang $=F r, 5^{\text {th }}$ April 2019;

Concluding observations on the twenty-first to twenty-third periodic reports of United Kingdom of Great Britain and Northern Ireland, Committee on the Elimination of Racial Discrimination, CERD/C/GBR/CO/21-23, 26 August 2016, https:// tbinternet.ohchr.org/Treaties/CERD/Shared\%20Documents/GBR/CERD_C_ GBR_CO_21-23_24985_E.pdf, 3th April 2019;

Convention for the Protection of Human Rights and Fundamental Freedoms (CETS No.005), 04.11.1950. - EKLjP, https://rm.coe.int/1680063765, 4 ${ }^{\text {th }}$ April 2019;

Etinski R., „Specific Features of Human Rights Guaranteed by the Aarhus Convention“, Zbornik radova PFNS, 2/2013, 79-92;

Etinski R., „Primena načela uti possidetis u sporu o granici između Burkina Faso i Malija“, Zbornik radova PFNS, 3/2013, 43-59;

Hmg Floats Proposal for Marine Reserve Covering the Chagos Archipelago (British Indian Ocean Territory), https://wikileaks.org/plusd/cables/09LONDON1156_a. html, 15th April 2019; 
ICJ, Case Concerning the Frontier Dispute (Burkina Faso/Republic of Mali), Judgment of 22 December 1986, https://www.icj-cij.org/files/case-related/69/069-19861222JUD-01-00-EN.pdf, 26th May 2019;

ICJ, Legal Consequences of the Separation of the Chagos Archipelago From Mauritius In 1965, 2019, https://www.icj-cij.org/files/case-related/169/169-2019022501-00-EN.pdf, 1th April 2019;

International Covenant on Civil and Political Rights 1960, https://treaties.un.org/doc/ publication/unts/volume\%20999/volume-999-i-14668-english.pdf, 4th April 2019.;

International Convention on the Elimination of All Forms of Racial Discrimination Adopted and opened for signature and ratification by General Assembly resolution 2106 (XX) of 21 December 1965, https://www.ohchr.org/Documents/ ProfessionalInterest/cerd.pdf, 4th April 2019.;

Gifkins J., Jarvis S., Ralph J., ,Global Britain in the United Nations“, https://www. una.org.uk/sites/default/files/UNA-UK_GlobalBritain_20190207d.pdf, 14 ${ }^{\text {th }}$ April 2019, 1-16;

Koskenniemi M., From Apology to Utopia - The Structure of International Legal Argument, Helsinki 1989;

Raoof A., „Still dispossessed - the battle of the Chagos Islanders to return to their homeland",Minority Rights Group International, https://minorityrights.org/ wp-content/uploads/2015/07/MRG_Brief_Chagosv2.pdf, 11th April 2019, 1-8;

Sand P., „The Chagos Archipelago Cases: Nature Conservation Between Human Rights and Power Politics", Giuliana Ziccardi Capaldo (ed.), The Global Community Yearbook of International Law \& Jurisprudence, 2013 (I), 125-149;

Schwebel A., ,International Law and Indigenous People's Rights: What Next for the Chagossians", Fifty Years of the British Indian Ocean Territory: Legal Perspectives, Stephen Allen, Chris Monaghan (eds.), Springer International Publishing AG, part of Springer Nature, Cham, Switzerland, 2018, 319-357;

Submission to the Committee on the Elimination of Racial Discrimination By Minority Rights Group International, International Non-Governmental Organisation with ECOSOC Consultative Status, United Kingdom of Great Britain and Northern Ireland 90th Session, 2-26 August 2016., https://tbinternet.ohchr.org/ Treaties/CERD/Shared\%20Documents/GBR/INT_CERD_IFN_GBR_24489_E.pdf, 4th April 2019;

Seventh periodic reports of States parties due in July 2012 United Kingdom, the British Overseas Territories, the Crown Dependencies - Consideration of Reports Submitted by States Parties Under Article 40 of the Covenant, Human Rights Committee, CCPR/C/GBR/7, 29 April 2013,https://assets.publishing. service.gov.uk/government/uploads/system/uploads/attachment_data/file/398147/ ccpr-c-gbr-7.pdf, 5th April 2019.;

The Arbitral Tribunal Award in the Matter of the Chagos Marine Protected Area Arbitration before an Arbitral Tribunal Constituted under Annex VII of the United Nations Convention on the Law of the Sea betweent the Republic of Mauritius and the United Kingdom of Great Britain and Northern Ireland, Permanent Court of Arbitration, 18 March 2015;. http://www.pcacases.com/pcadocs/ $M U-U K \% 2020150318 \% 20$ Award.pdf, $12^{\text {th }}$ April 2019.; 
Tubić B., „Rešavanje teritorijalnih sporova u međunarodnom pravu “, Zbornik radova PFNS, 4/2015, 1861-1875;

Tubić B., „Primena načela uti possidetis juris pri određivanju međudržavnih granica“, Zbornik radova PFNS, 3/2011, 647-662;

UN General Assembly Resolution A/RES/15/1514 (XV) 1960 „Declaration on the granting of independence to colonial countries and peoples" (Resolution 1514), https://undocs.org/A/Res/1514(XV), 2nd April 2019;

UN Convention on the Law of the Sea 1982, http://www.un.org/depts/los/convention_agreements/texts/unclos/unclos_e.pdf, 1th April 2019.;

UN General Assembly Resolution A/RES $/ 71 / 292$ 2017, https://www.un.org/en/ga/ search/view_doc.asp?symbol=A/RES/71/292, 1th April 2019;

UN court rejects UK's claim of sovereignty over Chagos Islands, https://www.theguardian.com/world/2019/feb/25/un-court-rejects-uk-claim-to-sovereignty-overchagos-islands, $15^{\text {th }}$ April 2019. 
Kristian Z. Kovač, student doktorskih studija

Univerzitet u Novom Sadu

Pravni fakultet u Novom Sadu

kristian.kovac@yahoo.com

\section{Međunarodnopravni aspekti slučaja arhipelaga Čagos}

Sažetak: Arhipelag Čagos je teritorija koja je 1965. godine odvojena od Mauricijusa, tadašnje kolonije Ujedinjenog Kraljevstva, na osnovu Lankasterskog sporazuma koji je Vlada kolonije Mauricijus zaključila sa Vladom Ujedinjenog Kraljevstva. Iste godine, Ujedinjeno Kraljevstvo osniva Britansku Teritoriju Indijskog Okeana koja obuhvata, između ostalog, i teritoriju ovog arhipelaga. Mauricijus je stekao nezavisnost 12. marta 1968. godine, dok je arhipelag Čagos ostao pod kolonijalnom upravom Ujedinjenog Kraljevstva. Mauricijus i dalje smatra arhipelag Čagos svojom teritorijom, i kontinuirano pokušava da upotrebi dostupne međunarodnopravne mehanizme u cilju osporavanja odvajanja arhipelaga Čagos 1965. godine. Autor istražuje međunarodnopravne aspekte dugogodišnjeg spora između Mauricijusa i Ujedinjenog Kraljevstva, poput pitanja depopulacije arhipelaga Čagos, pitanja proglašenja zaštićenog morskog područja od strane Ujedinjenog Kraljevstva 2010. godine povodom kojeg je Mauricijus inicirao arbitražni postuak na osnovu Konvencije Ujedinjenih nacija o pravu mora iz 1982. godine, kao i pitanja dekolonizacije i prava naroda na samoopredeljenje povodom kojeg je Generalna skupština Ujedinjenih nacija Rezolucijom 71/292 od 22. juna 2017. zatražila Savetodavno mišljenje Međunarodnog suda pravde. Savetodavno mišljenje Međunarodnog suda pravde doneto je 25. februara 2019. godine.

Ključne reči: dekolonizacija, pravo naroda na samoopredeljenje, ljudska prava, zaštićeno morsko područje, Međunarodni sud pravde.

Datum prijema rada: 25.04.2019. 